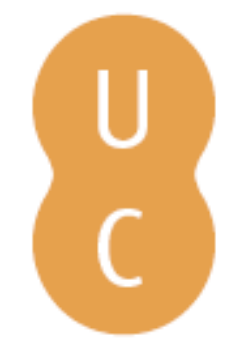

\title{
pommalina
}

Da República ao Império: considerações sobre as biografias de Plutarco

Autor(es): $\quad$ Silva, Maria Aparecida de Oliveira

Publicado por: Imprensa da Universidade de Coimbra

URL

persistente: URI:http://hdl.handle.net/10316.2/38230

DOI: $\quad$ DOI:http://dx.doi.org/10.14195/978-989-26-1053-5_11

Accessed : $\quad$ 26-Apr-2023 10:28:10

A navegação consulta e descarregamento dos títulos inseridos nas Bibliotecas Digitais UC Digitalis, UC Pombalina e UC Impactum, pressupõem a aceitação plena e sem reservas dos Termos e Condições de Uso destas Bibliotecas Digitais, disponíveis em https://digitalis.uc.pt/pt-pt/termos.

Conforme exposto nos referidos Termos e Condições de Uso, o descarregamento de títulos de acesso restrito requer uma licença válida de autorização devendo o utilizador aceder ao(s) documento(s) a partir de um endereço de IP da instituição detentora da supramencionada licença.

Ao utilizador é apenas permitido o descarregamento para uso pessoal, pelo que o emprego do(s) título(s) descarregado(s) para outro fim, designadamente comercial, carece de autorização do respetivo autor ou editor da obra.

Na medida em que todas as obras da UC Digitalis se encontram protegidas pelo Código do Direito de Autor e Direitos Conexos e demais legislação aplicável, toda a cópia, parcial ou total, deste documento, nos casos em que é legalmente admitida, deverá conter ou fazer-se acompanhar por este aviso.

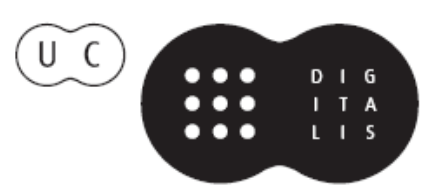




\section{Grécia e Roma no universo de Augusto}

\section{Ana Maria César Pompeu Francisco Edi de Oliveira Sousa (Orgs.)}

IMPRENSA DA UNIVERSIDADE DE COIMBRA

ANNABLUME 


\title{
Da República ao Império: considerações sobre as biografias de Plutarco (From Republic to Empire: Considerations on Plutarch's Biographies)
}

\author{
Maria Aparecida de Oliveira Silva ${ }^{263}$ (madsilva@usp.br) \\ Universidade de São Paulo
}

\begin{abstract}
Resumo - Plutarco é um autor importante para o estudo da transição do período republicano romano ao Império, visto que a maior parte de suas biografias dedicadas aos romanos pertence a esse período. Assim, o objetivo deste texto é apresentar a visão plutarquiana dos últimos anos da República Romana e a transição para o Império Romano.
\end{abstract}

Palavras-chave - Plutarco, Vidas Paralelas, República Romana, Império Romano.

Aвstract - Plutarch is a lead author for studying the transition from Roman Republic to Empire, since most of his biographies are dedicated to Romans of that period. The aim of this paper is to present Plutarch's vision about the last years of the Roman Republic and the transition to Roman Empire.

Keywords - Plutarch, Parallel Lives, Roman Republic, Roman Empire.

\section{INTRODUÇÃo}

Os últimos anos da história republicana de Roma são marcados por muitas crises internas e disputas entre facções políticas que resultam em diversas guerras civis. A nosso ver, as guerras e as dissensões internas do período republicano refletem a necessidade de o homem romano construir sua identidade diante de um novo horizonte que se abre com suas conquistas territoriais. Os questionamentos surgem no sentido de estabelecer quem é o homem romano, quem merece receber cidadania romana, quais são as diretrizes da política romana, quais são suas práticas culturais, etc. Tais inquietações levam os romanos da República a pensar sua língua, sua constituição política, a configuração de seu exército e sua estrutura social.

Sobre os últimos anos da República Romana e a sua passagem para o Império fundado por Augusto, temos doze biografias plutarquianas: Mário, Sertório, Sula, Crasso, Luculo, Pompeu, Cícero, Catão, César, Antônio, Bruto e Augusto, das

${ }^{263}$ Maria Aparecida de Oliveira Silva is visiting professor of the Postgraduate Programme in Classics at the University of São Paulo, and Research Professor of the Postgraduate Programme in History at the Federal University of São Paulo. Leader of the CNPq LABHAN Group Laboratory of Ancient History at the Federal University of Amapá. Researcher of the CNPq Linceu Group - Visions of Classical Antiquity, at São Paulo State University. Researcher of the Group "Retórica, Texto y Comunicación" at the University of Cádiz. Member of the Academic Council of the Seminar in History and Philosophy of Religions at the Autonomous University of Ciudad Juárez - Mexico. Her research interests are mainly Sparta, Plutarch and ancient biography. 
quais apenas a de Augusto não chegou até nós. No entanto, em seu tratado Ditos dos romanos, Plutarco relata quinze episódios envolvendo o imperador Augusto, de onde podemos traçar um breve perfil de sua personagem. Provavelmente parte dessas anedotas sobre Augusto compunha a sua biografia perdida, pois Plutarco costuma contar as mesmas anedotas nos tratados e nas biografias.

\section{Plutarco e os romanos da República}

\section{Mário}

De acordo com Plutarco, Mário era "nascido de pais completamente des-

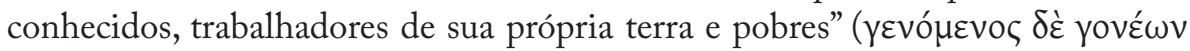

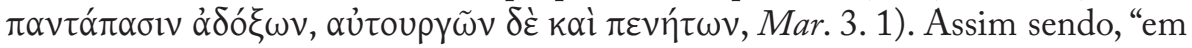
comparação com o modo de vida citadino e sua polidez, o seu era mais rústico,

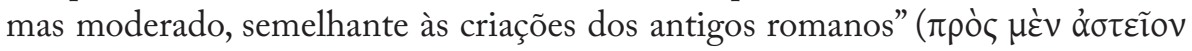

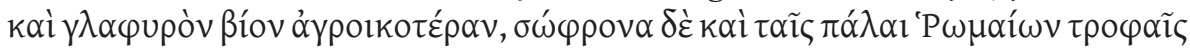
Ėolkũ̃ $\alpha$, Mar. 3.2) 264. Mário iniciou sua carreira militar como subalterno de Cipião Africano, destacando-se por ter costumes diferentes dos demais dos soldados, pois eram indisciplinados (Mar.3.3). Na visão de Plutarco, quando Mário lutou na Líbia contra Jugurta e de lá saiu vencedor e com grande fama (Mar.7-14), sua vitória foi resultado da sua estratégia militar, por ter usado os chamados "mulos de Mário”. Esses eram soldados treinados para realizar longas marchas, carregar pesadas bagagens e serem autossuficientes no campo de batalha. Plutarco afirma que "depois disso, os amantes dos trabalhos árduos, que executavam as ordens recebidas com alegria e em silêncio eram chamados de mulos marianos" ( $\mu \varepsilon \tau \grave{\alpha}$

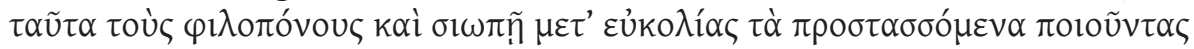

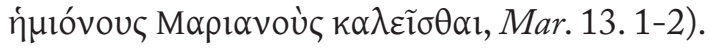

Plutarco destaca que o general romano ocupou seis vezes o posto de cônsul por suas vitórias militares, mas que, no auge do seu poder, assistiu à ascensão de Sula, que se tornou o seu maior rival (Mar. 23. 2-5) ${ }^{265}$. No entanto, segundo Plutarco, Mário e Sula não se enfrentaram militarmente porque a Guerra Social foi deflagrada. Terminada a guerra, Mário foi eleito cônsul pela sétima vez e logo partiu para guerrear contra Mitridates, ao lado de Sula; porém Plutarco afirma que Mário escondeu-se durante o conflito, para tramar a tomada do poder de Sula em Roma, sem sucesso (Mar. 32-35).

${ }^{264}$ Sobre a rusticidade de Mário, Buszard (2008: 207) aponta que Plutarco a vincula à ausência de uma paideia grega, dado característico das personagens plutarquianas do período republicano. Já Lavery (1971: 133) argumenta que a visão negativa de Plutarco a respeito de Mário advém de sua fonte de informação ser Memórias de Sula, seu inimigo declarado.

${ }^{265}$ Buszard (2005: 490ss) afirma que a ascensão de Sula é entendida por Plutarco como uma demonstração de sua fraqueza política, de seu caráter irresoluto. 


\section{Sula}

Conforme Plutarco, Sula descendia de família patrícia (Sull.1.1), ao contrário da origem humilde de seu rival, Mário. A partir desse aspecto, percebemos que Plutarco vê a dissensão interna em Roma como resultado da oposição entre patrícios e plebeus. De fato, parte considerável da biografia de Sula é destinada à disputa entre essas duas classes romanas, em um cenário de acirradas lutas, com a execução de muitos oposicionistas. Em razão disso, Plutarco enfatiza a discórdia predominante neste período da República, trata-a como uma época de terror e de abandono dos antigos costumes romanos. E, depois de Mário ter cometido suicídio, Sula assumiu o poder em Roma e promoveu a carnificina dos seus inimigos ${ }^{266}$ (Sull. 32.1-5):

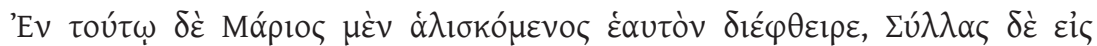

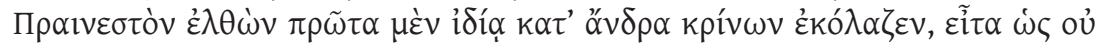

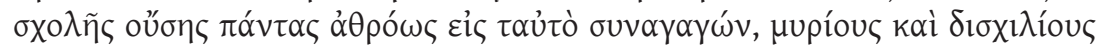

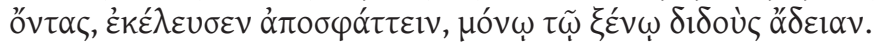

Nesse momento, Mário, ao ser apanhado, cometeu suicídio, e Sula foi para Preneste antes para julgar e punir cada homem em particular. Depois, como não tinha tempo livre para todos, reuniu uma multidão no mesmo lugar, sendo doze mil homens, e ordenou que fossem degolados, concedendo anistia somente ao seu anfitrião.

E Plutarco conta que, além de executar seus inimigos, Sula também cobrava de seus aliados que fizessem o mesmo por ele (Sull. 32. 5-6). Assim, Plutarco descreve um quadro de sucessivas guerras intestinas e de extermínio dos inimigos durante a época de Sula.

\section{Sertório}

De origem sabina, Sertório pertencia a uma família muito conhecida da cidade de Núrsia e, segundo Plutarco, sempre revelou grande interesse pelos assuntos relativos à guerra (Sert. 2.1-3). Depois de ter alcançado fama na Hispânia, Sertório foi eleito questor da Gália Cisalpina. Entretanto, por ser aliado de Mário, perdeu vários cargos em Roma para Sula (Sert. 4.3). Após a morte de Mário, Sertório retornou à Hispânia e travou muitas batalhas até se tornar o grande

${ }^{266}$ Como já foi apontado, Plutarco descreve o período republicano romano como o mais sangrento e eivado de discórdias e guerras, o mesmo foi notado por Candau Morón (2000: 456) na biografia de Sula, que é retratado como um homem rústico e cruel. Sobre essa visão plutarquiana do homem romano com um comportamento bárbaro, Silva (2014: 263ss) afirma que Plutarco concebe civilidade ao homem romano educado segundo os preceitos da paideia grega, especialmente pela filosofia. 
general e líder político dos lusitanos, por ter vencido Metelo (Sert. 12.5) - quando Metelo foi obrigado a pedir ajuda a Pompeu, e não por acaso, pois Sertório havia sofrido várias derrotas para ele. $\mathrm{Na}$ tentativa de manter o pouco poder que lhe restara, Sertório foi obrigado a fazer aliança com Mitridates de Comagene, porém o seu povo não aprovou a aliança e o assassinou sob a liderança de Perpena (Sert. 26).

\section{Crasso}

Embora o pai de Crasso tenha ocupado os cargos de censor, cônsul e governador da Hispânia Ulterior, Plutarco afirma que o romano teve uma vida simples e que era um homem prudente e moderado, porém era ávido por dinheiro (Crass. 1.6 e 2. 1). Quanto à sua formação, Plutarco conta que Crasso dedicou-se com afinco à retórica, com o intuito de ser convincente junto ao povo e de defender a República. O seu empenho foi tanto que Crasso se destacou diante de Pompeu, César e Cícero, famosos por sua brilhante capacidade oratória (Crass. 3. 3-5). E o mesmo quadro de disputa que havia entre Sula e Mário repete-se entre Crasso e Pompeu (7. 1-5 ${ }^{267}$. E Plutarco ainda assinala que a inveja de Crasso se estendia a César (7.6), em um momento político assim descrito por Plutarco (Crass. 7. 7):

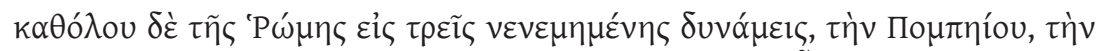

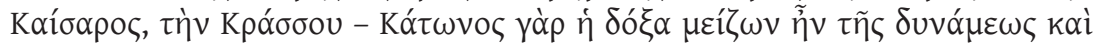

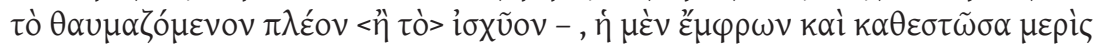

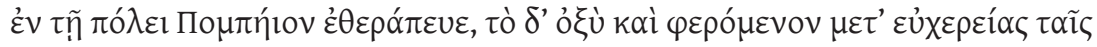

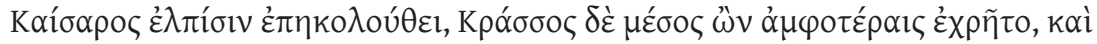

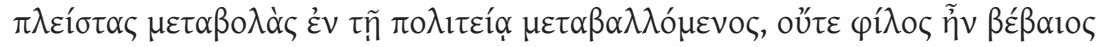

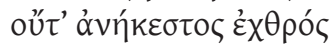

Em geral, Roma se dividia em três forças, a de Pompeu, a de César e a de Crasso - pois a reputação de Catão era maior que o seu poder, mais admirado que poderoso - a parte moderada e conservadora na cidade atendia Pompeu, e a radical e seguidora das inconsequências de César o acompanhava com esperança, enquanto Crasso estava no meio e se utilizava de ambas, realizando muitas mudanças em sua política, não era um amigo certeiro nem um inimigo incurável.

De acordo com Plutarco, quando eclodiu a insurreição dos gladiadores de Cápua, Crasso lutou bravamente contra eles. Contudo, a empreitada de Crasso aumentou a glória de Pompeu, uma vez que cinco mil escravos fugiram da batalha e foram mortos por Pompeu, que os encontrou por acaso no seu caminho (Crass. 11.2-4). Depois disso, formou-se o triunvirato de César, Pompeu e Crasso. Época

\footnotetext{
${ }^{267}$ Cf. Hillman 1992: 124-137.
} 
em que este último amargou uma derrota vergonhosa na batalha contra os partos, por seu exército ter abandonado a tradicional formação romana, arriscando-se a passar desordenadamente pelo vale, onde foram massacrados pelos partos ${ }^{268}$. Convém ressaltar que Plutarco subliminarmente demonstra que Crasso não fora agraciado pela célebre Fortuna dos romanos, muito pelo contrário, mostrou-se uma vítima dos infortúnios.

\section{Luculo}

Segundo Plutarco, o pai de Luculo foi condenado por malversação (não diz o nome do pai) e sua mãe Cecília tinha má reputação $(L u c .1 \text {. 1-2 })^{269}$. Por ter sido seu aliado e amigo desde a época da juventude, Sula dedicou a Luculo a sua obra intitulada Memórias (Luc. 1.5). Grande parte de sua biografia é destinada ao relato da participação de Luculo na guerra contra Mitridates e outros extensos capítulos à sua guerra contra os armênios ${ }^{270}$. Após essas batalhas, Luculo retornou a Roma para levar uma vida de luxo e de licenciosidade, afastando-se da vida política. E pouco depois de Cícero ter sido banido e de Catão ter sido mandado para Chipre ${ }^{271}$, Luculo morreu e foi enterrado no Campo de Marte, no mesmo local onde jazia Sula (Luc. 43.1-6).

\section{Pompeu}

Com um verso de Ésquilo, da peça Prometeu Libertado, "de odiado pai,

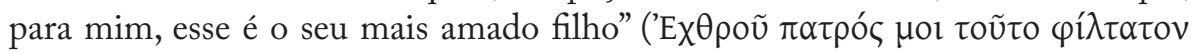
$\tau \varepsilon ́ k v o v)^{272}$, Plutarco inicia a biografia de Pompeu. Tal verso é utilizado para ilustrar o quanto Pompeu era amado tanto quanto seu pai Estrabão era odiado pelo povo romano, pela sua crueldade (Pomp. 1.1-2). Paralelo que Plutarco traça tendo como referência a crueldade de Zeus e a bondade de seu filho Héracles, um por punir e outro por libertar Prometeu.

${ }^{268}$ Braund (1993: 468-474) traça um paralelo entre a composição da biografia de Crasso e a de uma peça teatral, a fim de demonstrar o conteúdo trágico que Plutarco lhe confere. Zadorojniy (1997: 169-182) já aponta para essa característica trágica da narrativa plutarquiana na biografia de Crasso, mas acrescenta que se trata de uma herança épica, da qual Plutarco é devedor.

${ }^{269}$ Lavery (1994: 262) afirma que não há motivo para que Plutarco insira a biografia de Luculo na sua obra, a não ser pelo fato de ele ter passado por Queroneia. No entanto, discordamos do autor por entendermos que Luculo se enquadra no cenário de guerras, disputas, luxúrias que Plutarco descreve como sendo próprio da República Romana, cenário que só será alterado com a intervenção de Bruto no assassínio de César, o que possibilitou a entrada de Augusto no poder, como o fundador do Império Romano e o ordenador do caos em que se encontrava Roma.

${ }^{270}$ Em um texto interessante, Missiakoulis (2006: 269-270) analisa os dados fornecidos por Plutarco sobre as provisões de guerra de Luculo.

${ }^{271}$ Cf. Jones 1982: 254-256.

${ }^{272}$ Fragmento de Prometeu Libertado (Nauck, Trag. Graec. Frag. ${ }^{2}$ p. 68). 
Pompeu, aliado de Sula, estabeleceu laços de parentesco com ele ao se casar com Emília, enteada de Sula. Nos demais capítulos, Plutarco relata como Pompeu sagrou-se vencedor em inúmeras batalhas ${ }^{273}$, com destaque para suas guerras contra Sertório, os piratas da Cilícia, Mitridates e os escravos rebeldes de Cápua. Plutarco ainda narra a Guerra Civil e a batalha de Farsália, quando Pompeu lutou contra César, sendo obrigado a fugir da Itália e se refugiar no Egito, lugar em que foi assassinado por ordem de Roma (Pomp. 76 e 77).

\section{Cícero}

Pertencente à ordem Equestre (Cic. 1. 1), Cícero exerceu vários cargos políticos, foi questor (Cic. 6. 1), edil (8.1), pretor (9.1) e cônsul (10.1). De acordo com Plutarco, Cícero era grande opositor de César e Catilina, mas foram suas críticas a Marco Antônio que selaram o seu destino. Plutarco relata que, por ser um voraz crítico da política romana ${ }^{274}$ de seu tempo, Cícero amealhou incontáveis inimigos e foi condenado ao exílio por Clódio (Cic. 28. 1-2). Mais tarde, Cícero retornou (33), exerceu o proconsulado (36.1) e vivenciou a Guerra Social (37). Após o término da guerra, o orador abandonou a política e se dedicou à educação dos jovens interessados no estudo da filosofia (40.1). No entanto, Cícero não se absteve da política por muito tempo e, quando retornou, despertou o ódio de Antônio, a ponto de este ordenar que sua cabeça fosse cortada, em razão do que escreveu nas Filípicas (Cic. 48.9-11).

\section{Catão, o Jovem}

Catão descendia de família aristocrata, ficou órfão muito jovem e foi criado na casa de Lívio Druso (Cat. Min. 1. 1) 275. Como descreve Plutarco (Cat. Min. 52. 1-3), Catão tornou-se célebre por fazer oposição a César:

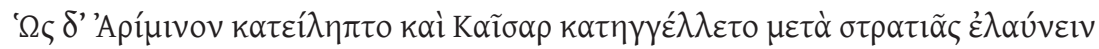

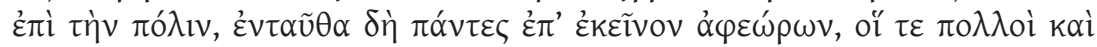

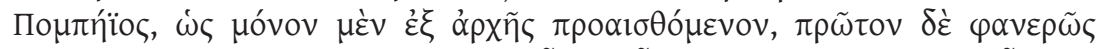

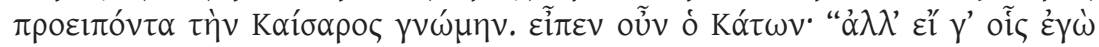

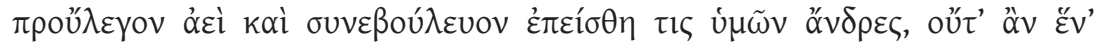

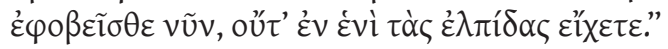

${ }^{273}$ Há um artigo de Mader (2006: 397-403) no qual aponta a necessidade de Pompeu, como qualquer outro general de seu tempo, de mostrar o seu triunfo de forma magistral.

${ }^{274}$ Quanto ao modo como Plutarco interpreta os discursos de Cícero e a sua oposição ferrenha a Catilina, consultar Pelling (1985: 311-329).

275 Quanto à interpretação de Plutarco sobre os familiares de Catão, o Jovem, consultar Dickison \& Means (1974: 210-215). 
Quando Arímino foi capturada, César anunciou que marcharia com o seu exército contra a cidade. Nesse momento, todos voltaram sua atenção para Catão, o povo e Pompeu, porque ele foi o único que os advertiu desde o início, o primeiro que claramente predisse o plano de César. Então, Catão disse: "mas, entre aqueles a quem eu sempre predisse e adverti, se um de vós tivesse se convencido, vós não temeríeis agora um único homem nem teríeis vossas esperanças em um só.”

Portanto, segundo Plutarco, por omissão dos cidadãos, César obteve sua vitória e dominou Roma, quando Catão, para não ser morto nas mãos de César, cometeu suicídio (Cat. Min. 70. 5) ${ }^{276}$.

\section{César}

O cenário que Plutarco descreve na biografia de César, como nas anteriores, é de disputa política e de guerras intestinas, no qual a sua maior rivalidade ocorreu com Sula, um parente de Mário (Caes. 1.1). Nosso autor segue registrando as batalhas travadas por César, anotando os cargos políticos e militares que ocupou, com destaque para as guerras das Gálias (Caes.15-24), a guerra contra Vercingétorix (25-26), o cerco de Alésia (27) e a Guerra Civil (28-47). No entender de Plutarco, tais batalhas foram responsáveis pelo fortalecimento militar e pela sedimentação do poder político de César (15.3). Plutarco tece ainda um breve relato sobre a passagem de César pelo Egito e o seu relacionamento com Cleópatra (Caes. 48-49). Ao longo da biografia de César, Plutarco relata vários triunfos, batalhas, guerras e empreendimentos militares do general romano, como se a vida dele se resumisse ao campo de batalha. $\mathrm{O}$ fim da vida de César é narrado por Plutarco como um episódio épico no qual demonstra sua coragem até mesmo diante da morte, acentuando sua revolta diante da traição de seus colegas senadores (Caes. 66. 6-8).

\section{Bruto}

Plutarco conta que Bruto descendia de Junio Bruto, para quem os romanos ergueram uma estátua de bronze no Capitólio, por ter expulsado os Tarquínios de Roma (Brut. 1. 1-2). No entanto, o antigo Bruto tinha um caráter duro, muito diferente do de seu descendente, segundo Plutarco: "com a educação, o aprendizado das letras; pela filosofia misturada ao seu caráter, com relação à sua natureza violenta e agradável, foi exortado para as ações práticas e parecia ter sido

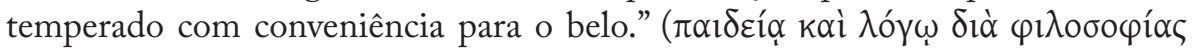

${ }^{276}$ Zadorojniy (2007: 216-230) demonstra que o significado do suicídio de Catão tem um significado filosófico, que Plutarco o associa a um filósofo e trata sua morte como um sacrifício para a liberdade política de Roma. 


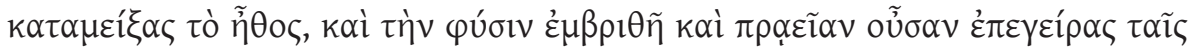

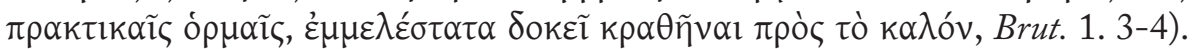

Conforme Plutarco, a participação de Bruto na Guerra Civil entre César e Pompeu foi surpreendente, pois se esperava que ele tomasse o partido de César, visto que seu pai havia sido morto por ordem de Pompeu, porém Bruto considerou os interesses públicos e se aliou ao outro (Brut. 4. 3-5). Convém ressaltar que Plutarco descreve o episódio tendo em mente a educação de Bruto, principalmente o seu aprendizado da filosofia, o que o teria tornado um homem sensato e distante das paixões pessoais, voltado para o bem público, para o que é belo. Plutarco destaca ainda a importância de Bruto na conspiração contra César, afirmando que, sem a sua participação, os conjurados teriam sido menos resolutos na ação (10.2). Após o assassinato de César, Bruto abandonou Roma e participou de algumas batalhas, com especial destaque para a de Filipos, exaustivamente descrita por Plutarco (38-49). Tal batalha ocorreu em 42 a.C. e se deu entre as forças do segundo triunvirato e as republicanas lideradas por Bruto e Cássio, principais envolvidos no assassinato de César. Os exércitos de Bruto e Cássio foram derrotados nessa batalha, por isso Bruto comete suicídio (53).

\section{Antônio}

Filho de Antônio, neto de Antônio, este executado por ordem de Mário (Ant. 1. 1), desposou Júlia, descendente da casa dos Césares (2. 1). Plutarco ressalta o ódio que Antônio nutria por Cícero (2. 2-4). Nosso autor conta que o jovem Antônio alia-se a César e incita a guerra entre as facções, e acrescenta: "por isso, Cícero escreveu em suas Filípicas que Helena era o princípio da Guerra de Troia enquanto Antônio o da guerra intestina, mas é claro que ele está men-

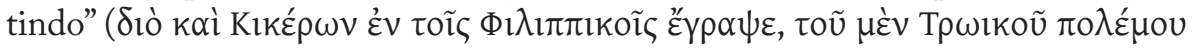

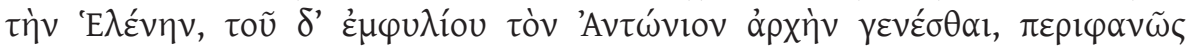
$\psi \varepsilon v \delta o ́ \mu \varepsilon v o \zeta$, Ant. 6. 2). Plutarco não concorda com o orador romano porque César era um homem resoluto e Antônio não tinha qualquer influência sobre ele. Sob a perspectiva do nosso autor, César era movido, como Alexandre e Ciro, pelo amor ao poder e pelo desejo de ser o primeiro (6.3) ${ }^{277}$. Então, Plutarco se serve de vários capítulos para demonstrar a tentativa de Antônio de ocupar o lugar de César, porém sem alcançar o sucesso almejado. Ao contrário de César, Antônio era suscetível, característica que Plutarco ressalta em sucessivos capítulos (25-36), tendo como exemplo principal o domínio de Cleópatra sobre Antônio ${ }^{278}$.

277 Wet (1990: 80-90) afirma que as interpretações de Plutarco sobre as ações de Antônio reproduzem o pensamento dos romanos de sua época.

${ }^{278}$ Duff (2004: 271-291) argumenta que a visão de Plutarco sobre a vida privada de Antônio revela um forte conteúdo trágico, o que o aproxima dos tragediógrafos do período clássico grego. O estilo poético da escrita plutarquiana é notado por Falivene (2007: 175-177), a autora traduz um poema de Kavafis inspirado na descrição de Plutarco sobre o abandono de Antônio pelo deus. 
$\mathrm{Na}$ visão de Plutarco, a influência de Cleópatra levou Antônio a se insurgir contra Roma, o que não ocorreu com César, porque Antônio era dependente de Cleópatra (Ant. 62). Assim, houve a Guerra Civil de Antônio contra Otaviano, que culminou na batalha de Ácio (60-77). O resultado foi uma vitória decisiva e arrasadora de Otaviano, que pôs fim ao crescente poder de Antônio. Tal batalha marcou o fim da República e início do Império Romano.

\section{Plutarco e Augusto}

Em seu tratado Ditos de Reis e imperadores Romanos (Regum et imperatorum apophthegmata), Plutarco narra quinze episódios nos quais apresenta um breve perfil de Augusto. No entanto, os episódios narrados por Plutarco não foram os seus únicos testemunhos sobre a vida de Augusto, sabemos que nosso autor redigiu uma biografia do imperador que não chegou até nós. Como é característico da composição das chamadas Obras Morais e de Costumes, Plutarco narra nelas episódios ou anedotas que também são relatados em suas biografias. Portanto, é provável que parte desses ditos estivesse na biografia perdida de Augusto.

No primeiro deles, Plutarco conta que Augusto convocou Antônio e lhe pediu que devolvesse o dinheiro de César, com o argumento de que queria devolvê-lo aos romanos. Porque Antônio não o atendeu, Augusto vendeu todo o patrimônio herdado de seu pai para cobrir a despesa, o que lhe trouxe a simpatia do povo e o ódio de Antônio (206E-207A) ${ }^{279}$. De outro modo, sem mencionar a cobrança do dinheiro, Plutarco relata o episódio da distribuição do dinheiro em Brut. 22. Com variantes, esse mesmo episódio é atestado por Apiano (B. C. 2. 28), Dion Cássio (45.3-5) e Suetônio (Aug. 83). Esses autores são unânimes na avaliação de que o recém-empossado imperador tinha como objetivo atrair a simpatia da grande massa que apoiava Júlio César.

O segundo dito é um episódio que envolve Augusto e Remeltaces, rei dos trácios, que abandonou Antônio para ser seu aliado. Enquanto brindavam sua aliança, Augusto disse que amava a traição, mas não o elogio de um traidor (207A), tal episódio também é relatado por Plutarco em Rom. 17. 4. Com essa ironia, Plutarco demonstra a habilidade de Augusto de tirar proveito daqueles que lhe interessam, sem se importar com o seu caráter.

Em outro dito, Plutarco conta que, quando os alexandrinos foram capturados e pensavam que sua cidade seria arruinada, Augusto disse que perdoava Alexandria por Ário, seu amigo, e por Alexandre, o seu fundador (207B) - tal episódio é relatado também em Ant. 80 e por Suetônio (Aug. 89). A admiração e o respeito demonstrados por Augusto denotam sua simpatia por Alexandre, o Grande; sentimentos que Plutarco reforça com um dito segundo o qual o imperador teria ficado espantado ao saber que Alexandre havia alcançado o auge aos

${ }^{279}$ Episódio é narrado ainda por Plutarco em Ant. 16. 
trinta e três anos e que considerava a hegemonia e a ordem em seus territórios mais importantes que suas conquistas (207D). $\mathrm{Na}$ anedota seguinte, Plutarco reitera a admiração de Augusto por Alexandre ao contar que o imperador enviou Gaio para as guerras na Armênia, recomendando-lhe a popularidade de Pompeu, a audácia de Alexandre e a sua sorte (207D).

Quando Augusto concede a Ário, um sacerdote de Alexandria, o cargo de governador na Sicília, Plutarco conta que o imperador recebeu um papel em que alguém dizia que o governador anterior era um ladrão e ainda lhe perguntava o que ele achava disso, então Augusto repondeu que concordava com ele (207B). Depreendemos deste registro que Plutarco visa demonstrar que Augusto buscava uma política pacificadora, diferente da adotada pelos romanos anteriores. Outro acontecimento relatado por nosso autor nos leva a crer nesta política pacifista do imperador. Quando o povo ateniense ofendeu o de Egina, na mesma época em que Augusto passava o inverno nesta cidade, o imperador não demonstrou qualquer irritação com o ocorrido, embora tenha ficado exasperado com o fato (207F).

Em outro episódio, Plutarco demonstra a preocupação de Augusto com a harmonia e a hegemonia de seu império. Quando o espartano Euricles foi acusado de maldizer o seu governo, Augusto ficou irritado com isso, mas logo voltou atrás e lhe recomendou uma punição branda depois de descobrir que ele era o último descendente de Brásidas (207F). Portanto, o imperador não quis despertar a ira dos espartanos, uma vez que o general era considerado um herói para eles. A busca pela harmonia nas relações com os outros povos requeria autocontrole do imperador.

Plutarco conta que Augusto ordenou ao filósofo Atenodoro que retornasse à sua casa e que este, antes de partir, o aconselhou a repetir as vinte e quatro letras do alfabeto quando sentisse que iria ficar irritado. Após ouvir essas palavras do filósofo, Augusto the pediu que ficasse, pois sentia que ainda precisava dele (207C-D).

Em outra anedota, Plutarco conta que Augusto ordenou a um grupo de jovens aristocratas que interrompessem seu tumulto, sem demonstrar qualquer irritação (207E).

Entretanto, segundo Plutarco, Augusto ainda demonstrava intolerância em algumas circunstâncias. Conforme vemos no dito em que Augusto ficou irado com Eros, um procurador do Egito, porque ele havia assado e comido uma codorniz invicta na luta, por isso ordenou que Eros fosse pendurado no mastro de um navio (207B). Igualmente, depois de ter instituído uma lei sobre o adultério, Augusto esmurrou uma jovem quando dizia que sua filha Júlia havia cometido adultério. Ciente da perda do seu autocontrole, segundo Plutarco, o imperador ficou arrependido e permaneceu sem se alimentar neste dia (207D).

Atenodoro não era o único confidente e conselheiro do imperador, Plutarco relata que Augusto também se apoiava em Mecenas, de quem costumava receber uma taça de presente a cada aniversário (207C). Plutarco revela ainda a 
preocupação de Augusto com o destino político de Roma, quando registra um dito no qual o imperador já pensava em Tibério como seu sucessor (207E). Por fim, nosso autor demonstra que o imperador não estava somente preocupado com o destino político de Roma, mas também com a permanência do recém-criado Império Romano, conforme depreendemos desta anedota (208A):

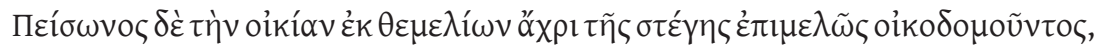

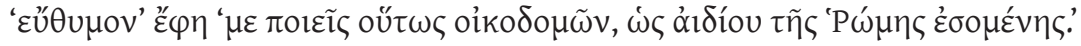

Quando Pisão construía sua casa cuidadosamente, da base até o telhado, disse: "Alegras-me por construíres tua casa assim, como se Roma fosse eterna."

\section{Conclusões}

Ao longo de nossa exposição dos fatos e das percepções de Plutarco sobre os acontecimentos dos últimos anos da República romana, percebemos que nosso autor retrata um quadro de completa desordem interna, nascida de acirradas disputas pelo poder em Roma. Nas biografias desse período, Plutarco demonstra que Roma estava sendo destruída por guerras e querelas internas entre os homens mais poderosos dessa época.

O cenário que Plutarco esboça, além de extenuantes guerras internas e externas, retrata ações destrutivas de patrícios e plebeus ávidos pelo controle político de Roma, que não mediam consequências, usando o exército como instrumento de intimidação e destruição dos seus opositores. Enfim, nosso autor nos mostra um quadro em que a violência e a intolerância imperam no cenário político romano. Em nenhuma das biografias dos romanos do período republicano, Plutarco relata a preocupação de um deles com o bem-estar de Roma e dos romanos, a questão central está apenas na obtenção do poder. Assim, o pensamento romano republicano estaria voltado para aspirações individuais, não coletivas.

Dentro deste quadro caótico, surgiu a figura de Otaviano que se tornou $\mathrm{Au}-$ gusto, um imperador jovem. Embora tivesse um temperamento instável e muita ambição pelo poder, Augusto construiu a paz necessária para o crescimento de Roma. Plutarco nos mostra que Augusto foi importante para a pacificação do Império Romano, tanto na sua política interna como na sua relação com os povos conquistados, encerrando um período de completa desordem. Não por acaso, Augusto é tratado como o pacificador de Roma, apesar de ter executado todos os opositores do seu governo e ter administrado com rigor os territórios dominados pelos romanos. Assim, segundo Plutarco, o governo de Augusto representa uma nova época em Roma, um período marcado pela paz interna e por uma relativa tranquilidade nas relações externas, o que impulsiona o crescimento do Império Romano em todo o Mediterrâneo. 


\section{REFERÊNCIAS BIBLIOGRÁFICAS}

\section{Edições}

Nachstädt, W. (1971), Plutarchi Moralia. 2. 1. Leipzig.

Ziegler, K. (1959-1971), Plutarchi Vitae Parallelae. Leipzig.

\section{Livros e Artigos}

Braund, D. (1993), "Dionysiac Tragedy in Plutarch, Crassus”, CQ 43: 468-474.

Buszard, B. (2005), "The Decline of Roman Statesmanship in Plutarch's Pyrrhus-Marius”, CQ 55: 481-497.

Buszard, B. (2008), "Caesar's Ambition: a Combined Reading of Plutarch's Alexander-Caesar and Pyrrhus-Marius”, TAPhA 138: 185-215.

Candau Morón, J. M.(2000), "Plutarch's Lysander and Sulla: Integrated Characters in Roman Historical Perspective”, AJPh 121: 453-478.

Dickison, S. K. \& Means, T. (1974), "Plutarch and the Family of Cato Minor", CJ 69: 210-215.

Duff, T. E. (2004), "Plato, Tragedy, the Ideal Reader and Plutarch's 'Demetrios and Antony", Hermes 132: 271-291.

Falivene, M. R. (2007), "La materia del poeta (Plutarco, "Vita di Antonio"75, 4-6; Costantino Kavafis, "Il dio abbandona Antonio")", QUCC 85: 175-177.

Hillman, P. (1992), "Plutarch and the First Consulship of Pompeius and Crassus", Phoenix 46: 124-137.

Jones C. P. (1982), "Plutarch, Lucullus 42, 3-4”, Hermes 110: 254-256.

Lavery, G. B. (1971), “Cicero’s 'Philarchia' and Marius”, $G$ \& $R$ 18: 133-142.

Lavery, G. B. (1994), "Plutarch's Lucullus and the Living Bond of Biography”, CJ 89: 261-273.

Mader, G. (2006), "Triumphal Elephants and Political Circus at Plutarch, "Pomp." 14.6", CW 99: 397-403.

Missiakoulis, S. (2006), "Plutarch and Lucullus' Applied Sampling”, AStat. 60: 269-270.

Pelling, C. B. R. (1985), "Plutarch and Catiline”, Hermes 113: 311-329.

Silva, M. A. O. (2014), Plutarco e Roma: o Mundo Grego no Império. São Paulo.

Wet, B.X. (1990), “Contemporary Sources in Plutarch's Life of Antony”, Hermes 118: 80-90.

Zadorojniy, A. V. (1997), “Tragedy and Epic in Plutarch's 'Crassus”, Hermes 125: 169-182.

Zadorojniy, A. V. (2007), “Cato’s Suicide in Plutarch”, CQ 57: 216-230. 